\title{
Fluoro-aluminoleakeite, $\mathrm{NaNa}_{2}\left(\mathrm{Mg}_{2} \mathrm{Al}_{2} \mathrm{Li}\right) \mathrm{Si}_{8} \mathrm{O}_{22} \mathrm{~F}_{2}$, a new mineral of the amphibole group from Norra Kärr, Sweden: description and crystal structure
}

\author{
R. Oberti ${ }^{1} *$, F. CÁmara ${ }^{1}$, F. C. Hawthorne ${ }^{2}$ and N. A. Ball ${ }^{2}$ \\ ${ }^{1}$ CNR-Istituto di Geoscienze e Georisorse, unità di Pavia, via Ferrata 1, I-27100 Pavia, Italy \\ ${ }^{2}$ Department of Geological Sciences, University of Manitoba, Winnipeg, Manitoba R3T 2N2, Canada
}

[Received 8 July 2009; Accepted 28 August 2009]

\section{ABSTRACT}

Fluoro-aluminoleakeite, ideally ${ }^{A} \mathrm{Na}^{B} \mathrm{Na}_{2}^{C}\left(\mathrm{Mg}_{2} \mathrm{Al}_{2} \mathrm{Li}\right)^{T} \mathrm{Si}_{8} \mathrm{O}_{22}^{W} \mathrm{~F}_{2}$, is a new mineral of the amphibole group from Norra Kärr, Sweden (IMA-CNMMNC 2009-012). It occurs in a proterozoic alkaline intrusion that mainly comprises a fine-grained schistose agpaitic nepheline-syenite (grennaite). Fluoroaluminoleakeite occurs as isolated prismatic crystals $0.10-2 \mathrm{~mm}$ long in a syenitic matrix. Crystals are light greenish-blue with a greenish-blue streak. It is brittle, has a Mohs hardness of 6 and a splintery fracture; it is non-fluorescent with perfect $\{110\}$ cleavage, no observable parting, and has a calculated density of $3.14 \mathrm{~g} \mathrm{~cm}^{-3}$. In plane-polarized light, it is pleochroic, $\mathrm{X}=$ pale green, $\mathrm{Y}=$ dark green, $\mathrm{Z}=$ pale green; $\mathrm{X}^{\wedge} a=62.9^{\circ}$ (in $\beta$ obtuse), $\mathrm{Y} \| b$. Fluoro-aluminoleakeite is biaxial negative, $\alpha=1.632(1)$, $\beta=1.638(1), \gamma=1.643(1) ; 2 \mathrm{~V}_{\text {obs. }}=98.0(4)^{\circ}, 2 \mathrm{~V}_{\text {calc. }}=95.5^{\circ}$.

Fluoro-aluminoleakeite is monoclinic, space group $C 2 / m, a=9.7043(5) \AA, b=17.7341(8) \AA, c=$ 5.2833(3) $\AA, \beta=104.067(4)^{\circ}, V=882.0(2) \AA^{3}, Z=2$. The eight strongest X-ray diffraction lines in the powder-diffraction pattern are $[d$ in $\AA,(I),(h k l)]$ : $2.687,(100),(\overline{3} 31,151) ; 4.435,(80),(021,040)$; $3.377,(80),(131) ; 2.527,(60),(\overline{2} 02) ; 8.342,(50),(110) ; 3.096,(40),(310) ; 2.259,(40),(\overline{1} 71, \overline{3} 12)$ and $2.557,(30),(002,061)$. Analysis, by a combination of electron microprobe and crystal-structure refinement, gives $\mathrm{SiO}_{2}$ 58.61, $\mathrm{Al}_{2} \mathrm{O}_{3}$ 7.06, $\mathrm{TiO}_{2}$ 0.32, $\mathrm{FeO}$ 3.27, $\mathrm{Fe}_{2} \mathrm{O}_{3}$ 6.05, $\mathrm{MgO}$ 8.61, $\mathrm{MnO} 0.73$, $\mathrm{ZnO} 0.43, \mathrm{CaO} 0.05, \mathrm{Na}_{2} \mathrm{O} 9.90, \mathrm{~K}_{2} \mathrm{O}$ 2.43, $\mathrm{Li}_{2} \mathrm{O} 1.62, \mathrm{~F} 3.37, \mathrm{H}_{2} \mathrm{O}_{\text {calc. }} 0.50$, sum 101.08 wt.\%. The formula unit, calculated on the basis of $24(\mathrm{O}, \mathrm{OH}, \mathrm{F}, \mathrm{Cl})$ p.f.u. with $(\mathrm{OH})+\mathrm{F}=2$ a.p.f.u., is ${ }^{A}\left(\mathrm{Na}_{0.65}\right.$ $\left.\mathrm{K}_{0.43}\right)_{\Sigma=1.09}{ }^{B}\left(\mathrm{Na}_{1.99} \mathrm{Ca}_{0.01}\right)_{\Sigma=2.00}{ }^{C}\left(\mathrm{Mg}_{1.77} \mathrm{Fe}_{0.38}^{2+} \mathrm{Mn}_{0.09} \mathrm{Zn}_{0.04} \mathrm{Fe}_{0.63}^{3+} \mathrm{Al}_{1.16} \mathrm{Ti}_{0.03} \mathrm{Li}_{0.90}\right)_{\Sigma=5.00}{ }^{T} \mathrm{Si}_{8.00}$ $\mathrm{O}_{22}{ }^{W}\left(\mathrm{~F}_{1.47} \mathrm{OH}_{0.53}\right)_{\Sigma=2.00}$. Crystal-structure analysis shows ${ }^{\mathrm{C}} \mathrm{Li}$ to be completely ordered at the $M(3)$ site, and provided reliable site populations. Fluoro-aluminoleakeite is related to the end-member leakeite, ${ }^{A} \mathrm{Na}^{B} \mathrm{Na}_{2}{ }^{C}\left(\mathrm{Mg}_{2} \mathrm{Fe}_{2}^{3+} \mathrm{Li}\right){ }^{T} \mathrm{Si}_{8} \mathrm{O}_{22}{ }^{W}(\mathrm{OH})_{2}$, by the substitutions ${ }^{C} \mathrm{Fe}^{3+} \rightarrow{ }^{C} \mathrm{Al}$ and ${ }^{W} \mathrm{~F} \rightarrow{ }^{W}(\mathrm{OH})$.

KEYwords: Fluoro-aluminoleakeite, new amphibole, lithium, electron microprobe analysis, optical properties, crystal-structure refinement, Norra Kärr, Sweden.

\section{Introduction}

THE new amphibole species fluoro-aluminoleakeite was found during systematic work on localities where the presence of Li-rich amphiboles, possibly as new species, was considered

* E-mail: oberti@crystal.unipv.it

DOI: 10.1180/minmag.2009.073.5.817 feasible. Lithium is a major constituent in amphibole (Oberti et al., 2007). Amphiboles have the general formula $A_{0-1} B_{2} \quad C_{5} \quad T_{8} \mathrm{O}_{22}$ $(\mathrm{OH})_{2}$, where $A$ are [8]- to [12]-coordinated cations, $B$ are [6]- to [8]-coordinated medium $\left(\mathrm{Li}, \mathrm{Mg}, \mathrm{Fe}^{2+}\right)$ or large $(\mathrm{Na}, \mathrm{Ca})$ cations, $C$ are [6]coordinated cations, and $T$ are [4]- coordinated cations. The occurrence of ${ }^{B} \mathrm{Li}$ has long been known in holmquistite [root composition $\left.\mathrm{Li}_{2}\left(\mathrm{Mg}_{3} \mathrm{Al}_{2}\right) \mathrm{Si}_{8} \mathrm{O}_{22}(\mathrm{OH})_{2}\right]$ and in clinoholmquistite (Ginsburg, 1965); however, the latter was 
recently discredited by Oberti et al. (2005). $C$-group $\mathrm{Li}$, strongly ordered at the $M(3)$ site, was first identified as a major constituent in leakeite $\left[{ }^{A} \mathrm{Na}^{B} \mathrm{Na}_{2}{ }^{C}\left(\mathrm{Mg}_{2} \mathrm{Al}_{2} \mathrm{Li}\right)^{T} \mathrm{Si}_{8} \mathrm{O}_{22}{ }^{W}(\mathrm{OH})_{2}\right.$, Hawthorne et al., 1992] and kornite $\left[{ }^{A} \mathrm{~K}^{B} \mathrm{Na}_{2}\right.$ ${ }^{C}\left(\mathrm{Mg}_{2} \mathrm{Mn}_{2}^{3+} \mathrm{Li}^{T}{ }^{T} \mathrm{Si}_{8} \mathrm{O}_{22}{ }^{W}(\mathrm{OH})_{2}\right.$, Armbruster et al., 1993] and has since been found in the oxoamphibole dellaventuraite $\left[{ }^{A} \mathrm{Na}^{B} \mathrm{Na}_{2}\right.$ ${ }^{C}\left(\mathrm{MgMn}_{2}^{3+} \mathrm{LiTi}^{4+}\right)^{T} \mathrm{Si}_{8} \mathrm{O}_{22}{ }^{\mathrm{W}} \mathrm{O}_{2}$, Tait et al., 2005]. More recently, identification of pedrizites [with the root composition ${ }^{A} \mathrm{Na}^{B} \mathrm{Li}_{2}{ }^{C}\left(\mathrm{Mg}_{2} \mathrm{Al}_{2} \mathrm{Li}\right)$ ${ }^{T} \mathrm{Si}_{8} \mathrm{O}_{22}{ }^{W}(\mathrm{OH})_{2}$; a recent review of the known compositions is given by Oberti et al. 2009] showed that $\mathrm{Li}$ can be both a $B$-group and a $C$-group cation, and that complete $\mathrm{Na}_{1} \mathrm{Li}_{-1}$ exchange is possible within the $B$ group (Oberti et al., 2003a). This latter point was investigated on different synthetic systems by Iezzi et al. (2003) and Della Ventura et al. (2005).

A significant amount of $\mathrm{Li}\left(1.15\right.$ wt. $\% \mathrm{Li}_{2} \mathrm{O}$, corresponding to 0.65 atoms per formula unit, a.p.f.u.) was reported by Sundius (1945) in amphiboles from Norra Kärr (Sweden). Norra Kärr is the type locality of eckermannite [ideally $\left.{ }^{A} \mathrm{Na}^{B} \mathrm{Na}_{2}{ }^{C}\left(\mathrm{Mg}_{4} \mathrm{Al}\right)^{T} \mathrm{Si}_{8} \mathrm{O}_{22}{ }^{W}(\mathrm{OH})_{2}\right]$, which has the charge arrangement most suitable for ${ }^{C} \mathrm{Li}$ incorporation in amphiboles according to the coupled exchange ${ }^{M(2,3)}\left(\mathrm{Mg}, \mathrm{Fe}^{2+}\right)_{-2}{ }^{M(3)} \mathrm{Li}_{1}$ ${ }^{M(2)}\left(\mathrm{Al}, \mathrm{Fe}^{3+}\right)_{1}$ (Hawthorne et al., 1994). Investigation of two rock samples from this locality, kindly provided by the well known mineral collectors Renato and Adriana Pagano (Cinisello Balsamo Italy), led to the discovery of the new species fluoro-aluminoleakeite (IMACNMNC 2009-012). This paper reports its characterization and mineral description.

\section{Occurrence}

The rock sample examined in this work (code 9717 in the Pagano's collection) was found at Norra Kärr, Gränna, Jönköping, Småland, Sweden (latitude $58^{\circ} 06^{\prime} \mathrm{N}$, longitude $14^{\circ} 40^{\prime} \mathrm{E}$ ). Citing Holtstam (1998), the Norra Kärr locality is a small oval $(1200 \mathrm{~m}$ long and $400 \mathrm{~m}$ wide at the surface) Proterozoic alkaline intrusion, composed mainly of fine-grained schistose agpaitic nepheline-syenite (grennaite). The petrological and genetic aspects of Norra Kärr have been described extensively by Adamson (1944), von Eckermann (1968), Blaxland (1977) and Kramm and Koark (1988). In the sample studied here, isolated prismatic crystals $0.10-2 \mathrm{~mm}$ long occur in a syenitic matrix, together with albite and aegirine.
The refined and analysed crystal of this work has the code 1122 in the amphibole database of the CNR-IGG Pavia. Holotype fluoro-aluminoleakeite is deposited at the Department of Natural History, Royal Ontario Museum, Toronto, Ontario M5S 2C6, Canada, specimen number M53897.

\section{Physical and optical properties}

Fluoro-aluminoleakeite is light greenish-blue, and has a vitreous lustre. It has a greenish-blue streak and shows no fluorescence under long-wave or short-wave UV light. Fluoro-aluminoleakeite has a Mohs hardness of $\sim 6$ and is brittle with a splintery fracture; it has the characteristic perfect $\{110\}$ cleavage of monoclinic amphiboles, intersecting at $\sim 56^{\circ}$. The calculated density is $3.14 \mathrm{~g} \mathrm{~cm}^{-3}$.

A spindle stage was used to orientate a crystal for measurement of refractive indices and $2 \mathrm{~V}$ by extinction curves (Bartelmehs et al., 1992). The optical orientation was determined by transferring the crystal from the spindle stage to a singlecrystal diffractometer and measuring the relative axial relations by X-ray diffraction. In transmitted light, fluoro-aluminoleakeite is pleochroic with $X$ $=$ pale green, $Y=$ dark green, $Z=$ pale green, $X^{\wedge} a$ $=62.9^{\circ}$ (in $\beta$ obtuse) and $Y \| b$. It is biaxial negative with indices of refraction $\alpha=1.632(1), \beta$ $=1.638(1), \gamma=1.643(1)$ measured with gelfiltered $\mathrm{Na}$ light $(\lambda=589.9 \mathrm{~nm}) ; 2 \mathrm{~V}_{\text {obs. }}=$ 98.0(43), $2 \mathrm{~V}_{\text {calc. }}=96.9^{\circ}$.

\section{Chemical composition}

Fluoro-aluminoleakeite was analysed primarily by electron microprobe using a Cameca SX100 operating in wavelength-dispersive mode with an accelerating voltage of $15 \mathrm{kV}$, a probe current of $10 \mathrm{nA}$, a final beam diameter of $5 \mu \mathrm{m}$, peakcount times of $20 \mathrm{~s}$ and background-count times of $10 \mathrm{~s}$. The following standards (X-ray lines and analysing crystals) were used: synthetic fluoro-

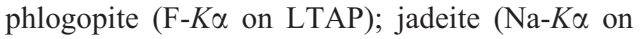
TAP); periclase (Mg-K $\alpha$ on LTAP); corundum(Al- $K \alpha$ on TAP); wollastonite ( $\mathrm{Si}-K \alpha$

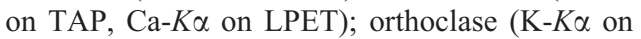
LPET); rutile (Ti-K $\alpha$ on LPET); Mn metal (Mn$K \alpha$ on LLIF); magnetite (Fe- $K \alpha$ on LLIF); $\mathrm{Zn}$ metal ( $\mathrm{Zn}-K \alpha$ on LLIF).

Data reduction was carried out using the $\varphi(\rho Z)$ procedure of Pouchou and Pichoir (1985). Lithium was derived by SREF (Structure REFinement, see section on crystal-structure refinement), and the $\mathrm{Fe}^{3+} / \mathrm{Fe}^{2+}$ ratio was derived 
so as to attain charge balance with the calculated amount of $\mathrm{Li}_{2} \mathrm{O}$. The average of 10 analyses on a single grain is given in Table 1 . The refined mean bond lengths at the $M$ sites show that both $\mathrm{Fe}$ and $\mathrm{Mn}$ are in the divalent state. The end-member formula is $\mathrm{NaNa}_{2}\left(\mathrm{Mg}_{2} \mathrm{Al}_{2} \mathrm{Li}\right) \mathrm{Si}_{8} \mathrm{O}_{22} \mathrm{~F}_{2}$, which corresponds to $\mathrm{SiO}_{2}$ 60.60, $\mathrm{Al}_{2} \mathrm{O}_{3} 12.86, \mathrm{MgO}$ 10.16, $\mathrm{Na}_{2} \mathrm{O}$ 11.72, $\mathrm{Li}_{2} \mathrm{O}$ 1.88, F 4.79, Total 100.00 wt. $\%$. The compatibility index $\left(1-K_{\mathrm{P}} / K_{\mathrm{C}}\right)$ is 0.0015 (superior).

\section{X-ray crystallography}

The powder-diffraction pattern was recorded from a small fragment on a Gandolfi camera with Fefiltered $\mathrm{Cu}-\mathrm{K} \alpha \mathrm{X}$-radiation. Cell dimensions were refined from the corrected $d$ values; the indexed powder pattern and refined cell dimensions are given in Table 2. Peak intensities reported in Table 3 as $I_{\text {obs. }}$ are those estimated by eye from the darkening on the film; those reported as $I_{\text {calc. }}$ have been calculated based on single-crystal data.

TABLE 1. Chemical composition (wt.\%) and unit formula (a.p.f.u.) for fluoro-aluminoleakeite.

\begin{tabular}{lrll}
\hline & & & \\
$\mathrm{SiO}_{2}$ & 58.16 & $\mathrm{Si}$ & 8.00 \\
$\mathrm{TiO}_{2}$ & 0.32 & $\mathrm{Sum} T$ & 8.00 \\
$\mathrm{Al}_{2} \mathrm{O}_{3}$ & 7.06 & & \\
$\mathrm{Fe}_{2} \mathrm{O}_{3}{ }^{*}$ & 6.05 & $\mathrm{Ti}^{4+}$ & 0.03 \\
$\mathrm{FeO}$ & 3.27 & $\mathrm{Al}$ & 1.16 \\
$\mathrm{MnO}$ & 0.73 & $\mathrm{Fe}^{3+}$ & 0.63 \\
$\mathrm{ZnO}$ & 0.43 & $\mathrm{Fe}^{2+}$ & 0.38 \\
$\mathrm{MgO}$ & 8.61 & $\mathrm{Mn}$ & 0.09 \\
$\mathrm{CaO}$ & 0.05 & $\mathrm{Zn}$ & 0.04 \\
$\mathrm{Na} 2 \mathrm{O}$ & 9.90 & $\mathrm{Mg}$ & 1.77 \\
$\mathrm{~K}_{2} \mathrm{O}$ & 2.43 & $\mathrm{Li}$ & 0.90 \\
$\mathrm{Li} \mathrm{O}_{2}^{*}$ & 1.62 & $\mathrm{Sum} C$ & 5.00 \\
$\mathrm{H}_{2} \mathrm{O}^{* *}$ & 0.50 & & \\
$\mathrm{~F}$ & 3.37 & $\mathrm{Ca}$ & 0.01 \\
$\mathrm{Sub}$ total & 102.50 & $\mathrm{Na}$ & 1.99 \\
$\mathrm{Less} \mathrm{O} \equiv \mathrm{F}$ & 1.42 & $\mathrm{Sum} B$ & 2.00 \\
$\mathrm{Total}$ & 101.08 & & \\
& & $\mathrm{~K}$ & 0.43 \\
& & $\mathrm{Na}$ & 0.65 \\
& & $\mathrm{Sum} A$ & 1.09 \\
& & $\mathrm{~F}$ & 1.47 \\
& & OH & 0.53 \\
& & Sum $W$ & 2.00 \\
& & & \\
\hline
\end{tabular}

* from structure refinement;

** based on $(\mathrm{OH})+\mathrm{F}=2$ a.p.f.u.
The possible space groups are $C 2 / \mathrm{m}, \mathrm{C} 2$ and $\mathrm{Cm}$; crystal-structure refinement confirmed the space group $C 2 / \mathrm{m}$.

\section{Crystal-structure refinement and crystal chemistry}

A single crystal was selected for data collection and structure refinement based on optical and diffraction properties. Unit-cell dimensions were calculated by least-squares refinement of the $d$ values obtained from 47 rows of the reciprocal lattice by measuring the centroid of gravity of each reflection and of the corresponding antireflection in the range $-60^{\circ}<2 \theta<60^{\circ}$. Two monoclinic equivalents were collected in the $2 \theta$ range $4-60^{\circ}$, and corrections were applied for absorption and Lp. Reflections with $I_{\mathrm{o}}>3 \sigma(I)$ were considered as observed during an unweighted full-matrix least-squares refinement on $F$ done using a program written at CNR-IGGPV specifically to deal with complex solidsolutions. Scattering curves for fully ionized scattering species were used at sites where chemical substitutions occur; neutral vs. ionized scattering curves were used at the $T$ and anion sites [except $\mathrm{O}(3)$ ]. Crystal data are summarized in Table 3. Table 4 reports the atomic coordinates and the components of the anisotropic-displacement parameters, and Table 5 reports selected interatomic distances and parameters related to the conformation of the double-chain of tetrahedra. A table listing the observed and calculated structure factors has been deposited with the Principal Editor of Mineralogical Magazine and is available from www.minersoc.org/pages/ e_journals/dep_mat_mm.html.

Site populations and $\mathrm{Li}$ quantification were derived from the results of EMP analysis and structure refinement. The present knowledge of the crystal-chemistry of $\mathrm{Li}$ in amphiboles allows determination of the amount and distribution of $\mathrm{Li}$ directly by SREF. The indications of the structure refinements are as follows: (1) the mean bond lengths of the tetrahedra $(<T 1-\mathrm{O}>=1.620 \AA$ and $<T 2-\mathrm{O}\rangle=1.621 \AA$ ) indicate that the amount of $\mathrm{Al}$ at the T(1) site, if any, is very low; (2) the mean bond length $(2.064 \AA)$ and site-scattering (28.85 e.p.f.u.) refined at the $M(1)$ site indicate that $\mathrm{Mg}$ and $\mathrm{Zn}$ occur at this site; (3) comparison of the refined- and calculated-bond distances at the three M octahedra (Table 6) indicates that Mn is in the divalent state and is ordered at the $M(3)$ site, and that $\mathrm{Fe}^{2+}$ is distributed between the $M(1)$ 


\section{R. OBERTI ET AL.}

TABLE 2. X-ray powder-diffraction data for fluoro-aluminoleakeite.

\begin{tabular}{|c|c|c|c|c|c|c|c|c|c|}
\hline$I_{\text {obs. }}$ & $I_{\text {calc. }}$ & $d_{\text {obs. }}(\AA)$ & $d_{\text {calc. }}(\AA)$ & $h k l$ & $I_{\text {obs. }}$ & $I_{\text {calc. }}$ & $d_{\text {obs. }}(\AA)$ & $d_{\text {calc. }}(\AA)$ & $h k l$ \\
\hline 20 & 14 & 8.907 & 8.866 & 020 & & 22 & & 2.254 & $\overline{3} 12$ \\
\hline 50 & 42 & 8.342 & 8.309 & 110 & $<5$ & 7 & 2.197 & 2.193 & $\overline{2} 42$ \\
\hline \multirow[t]{2}{*}{80} & 43 & 4.435 & 4.443 & 0 21 & 10 & 33 & 2.148 & 2.144 & 261 \\
\hline & 51 & & 4.433 & 040 & 5 & 14 & 2.128 & 2.121 & $\overline{3} 32$ \\
\hline 10 & 15 & 4.002 & 4.004 & 111 & 10 & 14 & 2.053 & 2.055 & 202 \\
\hline$<5$ & 6 & 3.626 & 3.629 & $\overline{2} 21$ & 10 & 11 & 2.000 & 2.004 & 351 \\
\hline 80 & 84 & $\mathbf{3 . 3 7 7}$ & 3.374 & 131 & $<5^{*}$ & 6 & 1.922 & 1.928 & 190 \\
\hline 20 & 25 & 3.225 & 3.226 & 240 & & 7 & & 1.920 & 421 \\
\hline 40 & 57 & 3.096 & 3.087 & 310 & 5 & 8 & 1.870 & 1.871 & $\begin{array}{lll}510 & 0\end{array}$ \\
\hline \multirow[t]{3}{*}{5} & 10 & 2.966 & 2.976 & $\overline{3} 11$ & $*$ & 8 & & 1.864 & 242 \\
\hline & 2 & & 2.963 & $\overline{2} 41$ & 5 & 6 & 1.833 & 1.835 & $\overline{1} 91$ \\
\hline & 2 & & 2.955 & 060 & $10^{*}$ & 10 & 1.777 & 1.777 & 191 \\
\hline 10 & 22 & 2.921 & 2.939 & 221 & & 7 & & 1.778 & 312 \\
\hline 20 & 30 & 2.766 & 2.770 & 330 & & 7 & & 1.773 & 0100 \\
\hline \multirow[t]{2}{*}{100} & 60 & 2.687 & 2.688 & $\begin{array}{lll}\overline{3} & 3 & 1\end{array}$ & $<5$ & 4 & 1.720 & 1.720 & $\overline{5} 12$ \\
\hline & 100 & & 2.685 & 151 & & 3 & & 1.718 & 172 \\
\hline \multirow[t]{2}{*}{30} & 24 & 2.557 & 2.567 & $\begin{array}{lll}0 & 0 & 2\end{array}$ & $<5$ & 7 & 1.685 & 1.687 & 133 \\
\hline & 36 & & 2.561 & 061 & $<5$ & 7 & 1.666 & 1.665 & $\overline{2} 82$ \\
\hline 60 & 59 & 2.527 & 2.523 & $\begin{array}{lll}\overline{2} & 0 & 2\end{array}$ & 15 & 27 & 1.638 & 1.637 & 461 \\
\hline \multirow[t]{2}{*}{$<5$} & 1 & 2.342 & 2.351 & 400 & & 13 & & 1.636 & $\begin{array}{lll}5 & 1 & 1\end{array}$ \\
\hline & 8 & & 2.349 & 350 & $<5$ & 12 & 1.613 & 1.613 & 480 \\
\hline \multirow[t]{2}{*}{20} & 21 & 2.294 & 2.299 & $\overline{3} 51$ & $<5$ & 10 & 1.590 & 1.589 & 1110 \\
\hline & 11 & & 2.284 & $\overline{4} 21$ & 10 & 11 & 1.576 & 1.576 & $\overline{4} 03$ \\
\hline 40 & 19 & 2.259 & 2.264 & 171 & & 21 & & 1.577 & 153 \\
\hline
\end{tabular}

$114.6 \mathrm{~mm}$ Debye-Scherrer powder camera with Gandolfi attachment using Ni-filtered $\mathrm{Cu}$ radiation $(\lambda \mathrm{Cu}-\mathrm{K} \alpha=$ $1.54178 \AA$ ). Intensities estimated visually (obs.) and calculated from SREF (calc.).

Not corrected for shrinkage, and no internal standard was used.

* lines omitted for unit-cell refinement.

Indexed on $a=9.691(6) \AA, b=17.731(9) \AA, c=5.290(3) \AA, \beta=103.92(5)^{\circ}, V=882.2(7) \AA^{3}$.

and $M(2)$ sites; in contrast, $\mathrm{Fe}^{3+}$ is ordered at the $M(2)$ site. Based on these constraints and on the results of the EMP analysis, the $\mathrm{Li}_{2} \mathrm{O}$ content was calculated, and the corresponding value of $\mathrm{Li}$ in a.p.f.u. is in good agreement with the refined site- scattering values at the $M(3)$ site. The final site populations (Table 6) are also in accord with the crystal-chemical constraint derived for ${ }^{C} \mathrm{Li}$ amphiboles, i.e. ${ }^{A}(\mathrm{Na}, \mathrm{K})={ }^{C} \mathrm{Li}$ (Oberti et al., 2003a). They differ only slightly from the unit

TABLE 3. Miscellaneous information for fluoro-aluminoleakeite.

$\begin{array}{ll}a(\AA) & 9.7043(5) \\ b(\AA) & 17.7341(8) \\ c(\AA) & 5.2833(3) \\ \beta & 104.067(4) \\ V\left(\AA^{3}\right) & 882.0(2) \\ \text { Space group } & C 2 / m \\ Z & 2 \\ D_{\text {calc. }}\left(\mathrm{g} \mathrm{cm}^{-3}\right) & 3.14\end{array}$

Crystal size $(\mu \mathrm{m})$

Radiation/monochromator

Total no. of reflections

No. unique reflections

No. observed reflections

$R_{\text {merge }} \%$

$R_{\text {obs }} \%$

$R_{\text {all }} \%$
$300 \times 115 \times 65$

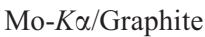

2590

1339

1071

1.80

1.63

2.66 
FLUORO-ALUMINOLEAKEITE

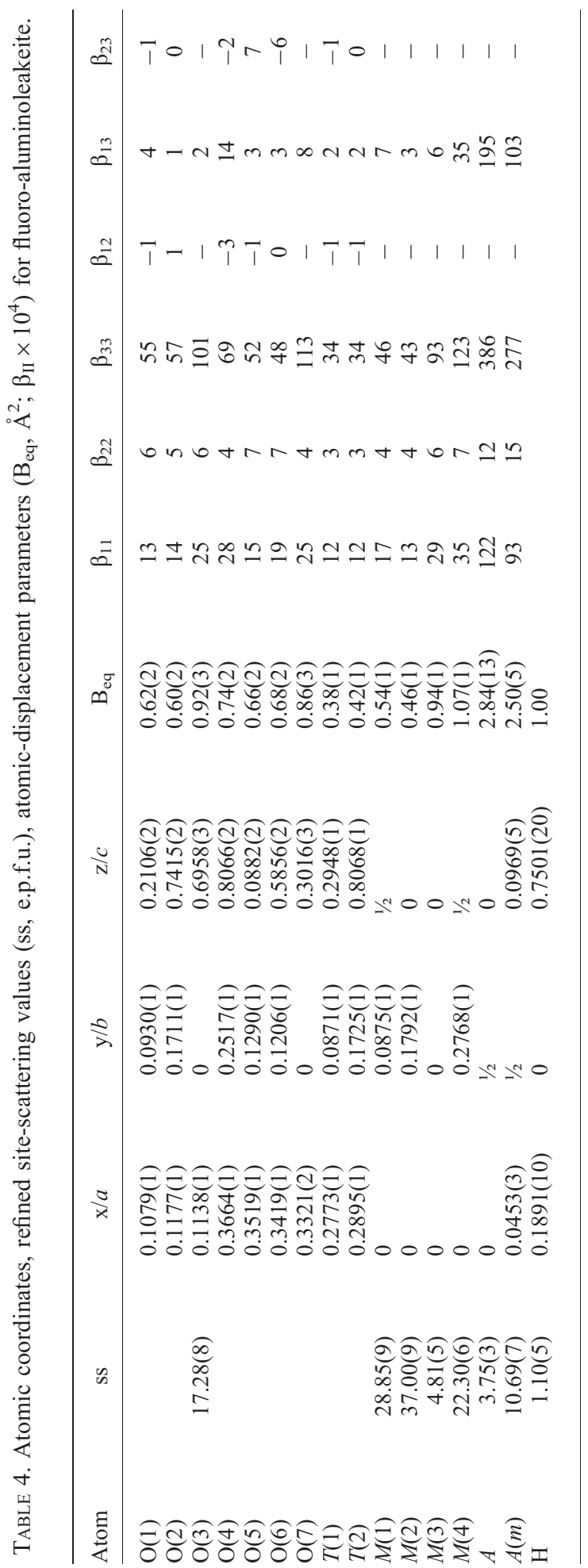




\section{R. OBERTI ET AL.}

TABLE 5. Selected interatomic distances $(\AA)$ and angles $\left(^{\circ}\right)$ in fluoro-aluminoleakeite.

$\begin{array}{lcll}T(1)-\mathrm{O}(1) & 1.599(1) & T(2)-\mathrm{O}(2) & 1.618(1) \\ T(1)-\mathrm{O}(5) & 1.628(1) & T(2)-\mathrm{O}(4) & 1.591(1) \\ T(1)-\mathrm{O}(6) & 1.624(1) & T(2)-\mathrm{O}(5) & 1.654(1) \\ T(1)-\mathrm{O}(7) & 1.630(1) & T(2)-\mathrm{O}(6) & 1.661(1) \\ <T(1)-\mathrm{O}> & 1.620 & <\mathrm{T}(2)-\mathrm{O}> & 1.631 \\ M(1)-\mathrm{O}(1) \times 2 & 2.055(1) & M(2)-\mathrm{O}(1) \times 2 & 2.025(1) \\ M(1)-\mathrm{O}(2) \times 2 & 2.103(1) & M(2)-\mathrm{O}(2) \times 2 & 1.987(1) \\ M(1)-\mathrm{O}(3) \times 2 & 2.035(1) & M(2)-\mathrm{O}(4) \times 2 & 1.893(1) \\ <M(1)-\mathrm{O}> & 2.064 & <M(2)-\mathrm{O}> & 1.968 \\ M(3)-\mathrm{O}(1) \times 4 & & \\ M(3)-\mathrm{O}(3) \times 2 & 2.119(1) & M(4)-\mathrm{O}(2) \times 2 & 2.395(1) \\ <M(3)-\mathrm{O}> & 2.160(1) & M(4)-\mathrm{O}(4) \times 2 & 2.362(1) \\ & 2.133 & M(4)-\mathrm{O}(5) \times 2 & 2.842(1) \\ A-\mathrm{O}(5) \times 4 & & M(4)-\mathrm{O}(6) \times 2 & 2.523 \\ A-\mathrm{O}(6) \times 4 & 2.800(1) & <M(4)-\mathrm{O}> & 2.952(1) \\ A-\mathrm{O}(7) \times 2 & 3.177(1) & & 2.767(1) \\ <A-\mathrm{O}> & 2.541(2) & A(m)-\mathrm{O}(5) \times 2 & 2.774(1) \\ T(1)-\mathrm{O}(5)-T(2) & 2.899 & A(m)-\mathrm{O}(5) \times 2 & 2.557(2) \\ T(1)-\mathrm{O}(6)-T(2) & & A(m)-\mathrm{O}(6) \times 2 & 3.111(2) \\ T(1)-\mathrm{O}(7)-T(1) & 133.7(1) & A(m)-\mathrm{O}(7) & 2.659(2) \\ \mathrm{O}(5)-\mathrm{O}(6)-\mathrm{O}(5) & 139.0(1) & A(m)-\mathrm{O}(7) & 2.813 \\ \mathrm{O}(6)-\mathrm{O}(7)-\mathrm{O}(6) & 142.6(1) & <A(m)-\mathrm{O}> & \end{array}$

formula reported in Table 1. In fact, the amount of $\mathrm{SiO}_{2}$ (wt.\%) obtained from EMPA does not allow $\mathrm{Al}$ to be a $T$ cation, and implies a number of $A$ cations $>1.0$ a.p.f.u. A small amount of ${ }^{T(1)} \mathrm{Al}$ is suggested from the refined $\langle T(1)-\mathrm{O}>$ and is in accord with the need for more trivalent cations (i.e. a slightly higher $\mathrm{Fe}^{3+} / \mathrm{Fe}^{2+}$ ratio) at the $M(2)$ site, which in turn derives from the very short value of the refined $\langle M(2)-\mathrm{O}>$ distance. Two distinct sites, $A(2)$ and $A(m)$, have been used to account for the highly anisotropic distribution of the electron density in the A cavity (Hawthorne et

TABLE 6. Site populations, site scattering and mean bond-lengths for fluoro-aluminoleakeite calculated based on EMP and SREF analysis.

\begin{tabular}{|c|c|c|c|c|c|}
\hline \multirow[t]{2}{*}{ Site } & \multirow[t]{2}{*}{ Site population (a.p.f.u.) } & \multicolumn{2}{|c|}{ Site scattering (e.p.f.u.) } & \multicolumn{2}{|c|}{ Mean bond length $(\AA)$} \\
\hline & & Refined & Calculated & Refined & Calculated \\
\hline$T(1)$ & $0.04 \mathrm{Al}+3.96 \mathrm{Si}$ & - & - & 1.620 & 1.620 \\
\hline$T(2)$ & $4 \mathrm{Si}$ & - & - & 1.631 & \\
\hline$M(1)$ & $1.76 \mathrm{Mg}+0.20 \mathrm{Fe}^{2+}+0.04 \mathrm{Zn}$ & 28.85 & 27.52 & 2.064 & 2.064 \\
\hline$M(2)$ & $1.13 \mathrm{Al}+0.75 \mathrm{Fe}^{3+}+0.09 \mathrm{Fe}^{2+}+0.03 \mathrm{Ti}$ & 37.00 & 37.19 & 1.968 & 1.972 \\
\hline$M(3)$ & $0.09 \mathrm{Mn}+0.91 \mathrm{Li}$ & 4.81 & 4.95 & 2.133 & 2.104 \\
\hline$\Sigma C$ & & 70.66 & 69.66 & & \\
\hline$M(4)$ & $1.99 \mathrm{Na}+0.01 \mathrm{Ca}$ & 22.30 & 22.09 & & \\
\hline$A(m)$ & $0.57 \mathrm{Na}+0.43 \mathrm{~K}$ & 14.44 & 14.44 & & \\
\hline $\mathrm{O}(3)$ & $1.40 \mathrm{~F}+0.60(\mathrm{OH})$ & 17.28 & 17.40 & & \\
\hline
\end{tabular}


al., 1996); in the fluoro-amphiboles ${ }^{A}(\mathrm{Na}, \mathrm{K})$ are ordered at the off-centred $\mathrm{A}(\mathrm{m})$ position, similar to all the fluoro-amphiboles refined so far.

\section{Discussion}

The identification of fluoro-aluminoleakeite is important for two reasons. The first is that until a couple of years ago, all characterized amphiboles with significant $\mathrm{Li}$ at the $M(3)$ site had ${ }^{C} \mathrm{Fe}^{3+}>$ ${ }^{C} \mathrm{Al}$, both in metamorphic and in magmatic environments, and thus end-member leakeite was defined as ${ }^{A} \mathrm{Na}^{B} \mathrm{Na}_{2}{ }^{C}\left(\mathrm{Mg}_{2} \mathrm{Fe}_{2}^{3+} \mathrm{Li}\right)$ ${ }^{T} \mathrm{Si}_{8} \mathrm{O}_{22}{ }^{W}(\mathrm{OH})_{2}$ (Hawthorne et al., 1992). Two possible explanations were suggested for the observation that ${ }^{C} \mathrm{Fe}^{3+}>{ }^{C} \mathrm{Al}$ : (1) it is a geochemical constraint related to crystallization of the amphibole from fluids rich in $\mathrm{Li}, \mathrm{Fe}, \mathrm{Mn}$; (2) it is related to some geometrical constraint requiring large trivalent cations at $M(2)$. The identification of fluoro-sodic-pedrizite at the Tastyg spodumene deposit, Siberia (Oberti et al., 2005), and now of fluoro-aluminoleakeite at Norra Kärr, indicates that a geometrical constraint is not operative, although the occurrence of $\mathrm{Al}$ at the $M(2)$ site is still correlated with that of $\mathrm{F}$ at the $\mathrm{O}(3)$ site, which in turn allows contraction of the $M(1)$ and $M(3)$ octahedra.

Fluoro-aluminoleakeite has a crystal-chemical feature deserving of comment. The $M(3)$ octahedron has a much shorter calculated mean bond length (based on stoichiometry) than the refined values (Table 6). Relaxation of some $M(1-3)$ octahedra in amphiboles is well known in compositions such as glaucophane, nyböite and fluoronyböite where the $M(1)$ and (especially) the $M(3)$ octahedra are larger than expected from the refined site-population (Oberti et al., 2003b). The maximum relaxation previously reported is $0.011 \AA(2.087 v s .2 .076 \AA)$ at the $M(3)$ site in fluoronyböite, much smaller than that in fluoroaluminoleakeite: $0.032 \AA(2.133$ vs. $2.101 \AA$; Table 6). Such relaxation was not present in the fluoro-ferroleakeites reported by Hawthorne et al. (1993), and the reason for relaxation has thus to be ascribed to the bond-valence requirements of this amphibole composition.

The second important issue arising from this work is the fact that the presence of Li was not recognized in the characterization of holotype eckermannite from Norra Kärr (Adamson, 1942), a problem first noted by Sundius (1945). The chemical and optical data reported by Fleischer (1944) (biaxial negative, $\alpha=1.636$ (bluish-green), $\beta=1.644$ (bright bluish-green), $\gamma=1.649$ (pale yellowish-green); $2 \mathrm{~V}($ obs. $)=74$ ) are compatible with those reported here for fluoro-aluminoleakeite. As a consequence, we are planning a systematic crystal-chemical work on eckermannitic amphiboles reported in the literature.

\section{Acknowledgements}

We are very grateful to Renato and Adriana Pagano for providing the rock sample investigated in this work and to Roberto Gastoni (CNR-IGG$\mathrm{PV})$ for skilful sample preparation for EMP analysis. This work was supported by the CNR project TA.01.004.002 and the MIUR-PRIN 2007 project 'Complexity in minerals: modulation, phase transition, structural disorder', by a Canada Research Chair in Crystallography and Mineralogy, by Natural Sciences and Engineering Research Council of Canada Discovery, Research Tools and Equipment, and Major Facilities Access grants, and by Canada Foundation for Innovation grants. Positive reviews from G. Iezzi and M.D. Welch are acknowledged.

\section{References}

Adamson, O.J. (1942) Eckermannite, a new alkali amphibole. Geologiska Föreningens $i$ Stockholm Förhandlingar, 64, 329-334.

Adamson, O.J. (1944) The petrology of the Nora Kärr district. Geologiska Föreningens $i$ Stockholm Förhandlingar, 66, 113-255.

Armbruster, T., Oberhänsli, R., Bermanec, V. and Dixon, R. (1993) Hennomartinite and kornite: two new $\mathrm{Mn}^{3+}$ rich silicates from the Wessels Mine, Kalahari, South Africa. Schweizerische Mineralogische und Petrographische Mitteilungen, 73, 349-355.

Bartelmehs, K.L., Bloss, F.D., Downs, R.T. and Birch, J.B. (1992) Excalibr II. Zeitschrift für Kristallographie, 199, 185-196.

Blaxland, A.B. (1977) Agpaitic magmatism at Norra Kärr? Rb-Sr isotopic evidence. Lithos, 10, 1-8.

Della Ventura, G., Redhammer, G.J., Iezzi, G., Hawthorne, F.C., Papin, A. and Robert, J.L. (2005). A Mossbauer and FTIR study of synthetic amphiboles along the magnesioriebeckite-ferri-clinoholmquistite join. Physics and Chemistry of Minerals, 32, 103-113.

Fleischer, M. (1944) New mineral names. American Mineralogist, 29, 455-456.

Ginsburg, I.V. (1965) Holmquistite and its structural variety clinoholmquistite. Trudy, Mineralogicheskiy Muzeya Akademiya Nauk SSSR, 16, 73-89. 


\section{R. OBERTI ET AL.}

Hawthorne, F.C., Oberti, R., Ungaretti, L. and Grice, J.D. (1992) Leakeite, $\mathrm{NaNa}_{2} \mathrm{Mg}_{2}\left(\mathrm{Mg}_{2} \mathrm{Fe}_{2}^{3+} \mathrm{Li}\right)$ $\mathrm{Si}_{8} \mathrm{O}_{22}(\mathrm{OH})_{2}$, a new amphibole from the Kajlidongri manganese mine, Jhabua district, Madhya Pradesh, India. American Mineralogist, 77, 1112-1115.

Hawthorne, F.C., Ungaretti, L., Oberti, R., Bottazzi, P. and Czamanske, G.K. (1993) Li: an important component in igneous alkali amphiboles. American Mineralogist, 78, 733-745.

Hawthorne, F.C., Ungaretti, L., Oberti, R. and Cannillo, E. (1994) The mechanism of ${ }^{[6]} \mathrm{Li}$ incorporation in amphiboles. American Mineralogist, 79, 443-451.

Hawthorne, F.C., Oberti, R. and Sardone, N. (1996) Sodium at the A site in clinoamphiboles: the effects of composition on patterns of order. The Canadian Mineralogist, 34, 577-593.

Holtstam, D. (1998) Jinshajiangite from the Norra Kärr alkaline intrusion, Jönköping, Sweden. Geologiska Föreningens $i$ Stockholm Förhandlingar, 120, $373-374$.

Iezzi, G., Della Ventura, G., Cámara, F., Pedrazzi, G. and Robert, J.L. (2003). ${ }^{\mathrm{B}} \mathrm{Na}-{ }^{\mathrm{B}} \mathrm{Li}$ solid-solution in Asite vacant amphiboles: synthesis and cation ordering along the ferri-clinoferroholmquistite-riebeckite join. American Mineralogist, 88 955-961.

Kramm, U. and Koark, H.J. (1988) Isotopic composition of galena lead from the Norra Kärr peralkaline complex, Sweden. Geologiska Föreningens $i$ Stockholm Förhandlingar, 110, 311-316

Oberti, R., Cámara, F., Ottolini, L. and Caballero, J.M. (2003a) Lithium in amphiboles: detection, quantification, and incorporation mechanisms in the compositional space bridging sodic and ${ }^{\mathrm{B}} \mathrm{Li}$-amphiboles. European Journal of Mineralogy, 15, 309-319.

Oberti, R., Boiocchi, M. and Smith, D.C. (2003b) Fluoronyböite from Jianchang (Su-Lu, China) and nyböite from Nybö (Nordfjord, Norway): description and comparison of two high-pressure amphibole endmembers. Mineralogical Magazine, 67, 769-782.

Oberti, R., Cámara, F. and Ottolini, L. (2005) Clinoholmquistite discredited: The new amphibole end-member fluoro-sodic-pedrizite. American Mineralogist, 90, 732-736.

Oberti, R., Hawthorne, F.C., Cannillo, E. and Cámara, F. (2007) Long-range order in amphiboles. Pp. 125-172 in: Amphiboles: Crystal Chemistry, Occurrence and Health Issues (F.C. Hawthorne, R. Oberti, G. Della Ventura and A. Mottana, editors). Reviews in Mineralogy and Geochemistry, 67, Mineralogical Society of America, Chantilly, Virginia, USA.

Oberti, R., Boiocchi, M., Ball, N.A. and Hawthorne, F.C. (2009) Fluoro-sodic-ferropedrizite, $\mathrm{NaLi}_{2}\left(\mathrm{Fe}_{2}^{2+} \mathrm{Al}_{2} \mathrm{Li}\right) \mathrm{Si}_{8} \mathrm{O}_{22} \mathrm{~F}_{2}$, a new mineral of the amphibole group from the Sutlug River, Tuva Republic, Russia: Description and crystal structure. Mineralogical Magazine, 73, 487-494.

Pouchou, J.L. and Pichoir, F. (1985) 'PAP' $\varphi(\rho Z)$ procedure for improved quantitative microanalysis. Pp. 104-106 in: Microbeam Analysis (J.T. Armstrong, editor). San Francisco Press, San Francisco, California, USA.

Sundius, N. (1945) The composition of eckermannite and its position in the amphibole group. Arsbok Sveriges Geologiska Undersökning, 39 (8), 3-7.

Tait, K.T., Hawthorne, F.C., Grice, J.D., Ottolini, L. and Nayak, V.K. (2005) Dellaventuraite, $\mathrm{NaNa}_{2}\left(\mathrm{MgMn}_{2}^{3+} \mathrm{Ti}^{4+} \mathrm{Li}\right) \mathrm{Si}_{8} \mathrm{O}_{22} \mathrm{O}_{2}$, a new anhydrous amphibole from the Kajlidongri Manganese Mine, Jhabua District, Madhya Pradesh, India. American Mineralogist, 90, 304-309.

von Eckermann, C.W.H. (1968) New contributions to the interpretation of the genesis of the Norra Kärr alkaline body in Southern Sweden, Lithos, 1, 76-88. 